\title{
PENGARUH KEBIJAKAN RELOKASI TERHADAP TINGKAT KEPUASAN PEGAWAI NEGERI SIPIL : STUDI PADA DIREKTORAT JENDERAL PERBENDAHARAAN KEMENTERIAN KEUANGAN REPUBLIK INDONESIA ${ }^{1}$
}

\author{
Lili Suheli \\ Direktorat Jenderal Perbendaharaan \\ Alamat Korespondensi: suheli@iuj.ac.jp
}

\section{INFORMASI ARTIKEL}

Diterima Pertama

28 Agustus 2017

Dinyatakan Diterima

20 Desember 2017

KATA KUNCI:

Kepuasan kerja, relokasi kerja, manajemen sumber daya manusia, kuisioner, survey

\section{KLASIFIKASI JEL:} J680

\begin{abstract}
ABSTRAK
For public institutions, human resource management is key to providing better public services. Therefore, exploration of factors, which may affect job satisfaction of employees, is necessary to ensure organization's goal has been achieved. This study aims to examine various factors relating to employee's satisfaction level pertaining to job relocation policy, wherein this policy is being implemented by the Directorate General of Treasury. 178 employees working at the DG of Treasury were taken as sample respondents. Questionnaires were used as a quantitative measurement to determine the correlation between job relocation factors and job satisfaction levels. The factors are future career advancement, compensation and organizational supports, location preference, family consideration and socio-cultural issues. The findings show that compensation and organizational supports have a salient effect on job satisfaction level, while location preference and socio-culture, statistically, have a significant affect on job satisfaction at a moderate level. Thus, this study has an implication on how to formulate a proper job relocation policy, especially for public institutions.
\end{abstract}

Bagi organisasi publik seperti institusi pemerintahan, mengatur Sumber Daya Manusia adalah kunci untuk mewujudkan pelayanan kepada masyarakat yang lebih baik. Oleh karena itu, menginvestigasi faktor-faktor apa saja yang dapat mempengaruhi kepuasan kerja para pegawai diperlukan untuk memastikan tercapainya tujuan organisasi yang diinginkan. Penelitian ini bertujuan untuk mengidentifikasi faktor-faktor yang dapat mempengaruhi tingkat kepuasan pegawai terkait kebijakan relokasi kerja, salah satu kebijakan dalam pengelolaan kepegawaian yang dilaksanakan oleh Direktorat Jenderal Perbendaharaan (DJPb). Sample dari 178 responden pegawai DJPb digunakan. Kuesioner digunakan sebagai alat metode pengukuran kuantitatif untuk mengukur hubungan antara faktor-faktor terkait relokasi kerja serta tingkat kepuasan pegawai. Faktor - faktor tersebut antara lain : peningkatan karir, kompensasi dan dukungan organisasi, preferensi lokasi, pertimbangan keluarga serta sosialkultural. Hasil penelitian menunjukan bahwa kompensasi dan dukungan organisasi merupakan faktor terpenting dalam menentukan tingkat kepuasan kerja, sedangkan preferensi lokasi dan aspek sosial kultural secara statistik mempengaruhi kepuasan kerja pada tingkat yang "moderat". Selanjutnya, penelitian ini dapat berdampak pada bagaimana memformulasikan kebijakan relokasi kerja yang tepat, terlebih lagi bagi institusi pemerintahan.

\footnotetext{
${ }^{1}$ artikel ini adalah versi pendek dari thesis yang berjudul The impact of job relocation policy on the employees' job satisfaction perception: The case of Directorate General Of Treasury of The Republic of Indonesia di Universitas Internasional Jepang
} 


\section{PENDAHULUAN}

\subsection{Latar Belakang}

Penerapan kebijakan yang efektif dalam manajemen SDM sangatlah penting. Namun, tidak semua orang dapat merasa puas dengan penerapan kebijakan-kebijakan tersebut. Cara dimana sebuah organisasi, baik itu organisasi publik atau swasta, menerapkan kebijakan tertentu dapat memiliki dampak terhadap performa organisasi tersebut (Beauregard \& Henry, 2009). Pada divisi atau bagian yang bertanggung jawab atas penempatan pegawai, menempatkan pegawai yang tepat pada posisi jabatan yang tepat memang cukup sulit, terlebih lagi ketika hal tersebut dilakukan oleh organisasi besar nasional. Menurut Rainey (2010), "semakin besar ukuran sebuah organisasi, tantangan terhadap manajemen SDM akan lebih besar; dengan demikian, para pengambil keputusan dalam organisasi wajib memiliki kemampuan manajemen SDM yang lebih tinggi" (hal. 51).

Berdasarkan kebutuhan pegawai, pembuat kebijakan dan pengelola SDM selayaknya melakukan upaya yang sangat serius dalam rangka menelaah kebutuhan dan kapasitas para pegawainya, berikut kepuasan kerja mereka. Ketika suatu organisasi meminta integritas dan profesionalisme, tanpa memberikan perhatian yang cukup terhadap kehidupan pribadi para pegawainya, hasilnya dapat berujung pada konflik antara pekerjaan dan kehidupan pribadi para pegawai (Qu \& Zhao, 2009). Sebagai tambahan, organisasi harus memberikan perhatian lebih terhadap dampak dari pengelolaan SDM dan kebijakan terkait SDM mereka terhadap kehidupan para pegawai secara menyeluruh, baik dalam bentuk menetapkan kebijakan yang tepat atau menciptakan dukungan yang memadai dalam rangka memecahkan dan meminimalisasi dampak negatif kebijakannya (Riemer, 2000). Oleh karena itu, strategi yang efektif untuk mengelola para pegawai meliputi penempatan tujuan strategis organisasi pada program-program dan kebijakan yang konsisten dan terintegrasi (Mello, 2006).

$\mathrm{DJPb}$ merupakan salah satu instusi pemerintahan terbesar di Indonesia yang memiliki kantor-kantor unit vertikal di setiap provinsi dan pegawai dalam jumlah yang cukup besar. Oleh karena itu, DJPb menjalankan kebijakan relokasi kerja (mutasi) dalam rangka meningkatkan kapasitas dan kapabilitas para pegawainya, selain itu juga sebagai sarana pengetahuan bagi para pegawai mengenai insitusi mereka dan para pemangku kepentingan (Bagian SDM DJPb, n.d). Bagian SDM suatu organisasi melaksanakan kebijakan tersebut dalam rangka memenuhi kebutuhan organisasi akan SDM di daerah tertentu dimana di sana membutuhkan SDM yang mumpuni, selain itu kebijakan ini juga dalam rangka peningkatan kapasitas dan kapabilitas pegawai sebagaimana yang disampaikan oleh Ortega (2006).

Terdapat banyak penelitian terkait hubungan antara kebijakan relokasi kerja dan kepuasan kerja pegawai dalam suatu organisasi. Akan tetapi, tidak banyak penelitian dimaksud yang dilaksanakan pada institusi pemerintah karena para pegawai negeri sipil biasanya tidak/kurang memiliki hak untuk menolak penugasan di tempat kerja yang baru, walaupun tempat kerja tersebut tidak sesuai dengan harapan dan keinginan mereka. Sebagai tambahan, tidak banyak pula penelitian yang mengangkat tema mengenai hubungan antara relokasi dan kepuasan kerja para pegawai pada negara-negara berkembang di Asia. Padahal, negera-negara tersebut masyarakatnya lebih majemuk serta memiliki latar belakang dan nilainilai masyarakat yang berbeda antara satu dengan yang lain dibanding dengan negara-negara di belahan dunia lainnya. Oleh karena itu, penelitian ini berusaha mengidentifikasi dan mengukur pengaruh variabel-variabel terkait kebijakan relokasi terhadap tingkat kepuasan kerja pegawai negeri sipil pada Direktorat Jenderal Perbendaharaan, Kementerian Keuangan Republik Indonesia. Diharapkan hasil penelitian ini dapat memberikan gambaran hubungan kedua variable tersebut, dilihat dari beberapa aspek, pada pegawai instansi pemerintahan di sebuah negara berkembang.

Penelitian ini juga akan menjelaskan aspekaspek terkait kebijakan relokasi yang dapat mempengaruhi tingkat kepuasan kerja para pegawai. Pengetahuan tersebut sangat diperlukan oleh para pengambil kebijakan pada bagian pengelolaan SDM, sama halnya dengan pihak yang memiliki otoritas dalam menentukan dan mengambil kebijakan terkait pelaksanaan kebijakan relokasi atau mutasi kerja. Setelah memahami aspek-aspek yang memiliki pengaruh cukup besar terhadap kehidupan personal para pegawai serta tingkat kepuasan kerja mereka, para pengambil kebijakan dapat membuat rancangan kebijakan relokasi yang lebih baik serta implementasi kebijakan yang lebih efektif dan efisien.

\subsection{Pertanyaan Penelitian}

Penelitian ini mencoba membahas bagaimana kebijakan relokasi pegawai yang berjalan saat ini mempengaruhi tingkat kepuasan kerja para pegawai. Lebih lanjut, penelitian ini juga bertujuan untuk mengidentifikasi faktor - faktor yang dapat mempengaruhi keputusan dan kesiapan para pegawai dalam menerima penugasan mutasi ke tempat kerja yang baru, tetapi tetap memiliki 
kepuasan yang tinggi. Pertanyaan penelitian ini sebagai berikut :

1. dengan mempertimbangkan peningkatan karir di masa depan serta dukungan dari organisasi, bagaimana persepsi para pegawai terhadap kebijakan relokasi yang dapat mempengaruhi kepuasan kerja mereka?

2. dengan mempertimbangkan dukungan keluarga dan kehidupan pribadi, bagaimana persepsi para pegawai terhadap kebijakan relokasi yang dapat mempengaruhi kepuasan kerja mereka?

3. dengan mempertimbangkan kompetensi sosialkultural dan kehidupan sosial, bagaimana persepsi para pegawai terhadap kebijakan relokasi yang dapat mempengaruhi kepuasan kerja mereka?

\section{KERANGKA TEORI DAN PENGEMBANGAN HIPOTESIS}

Variabel yang digunakan dalam penelitian ini yaitu : (1) relokasi kerja sebagai variable independen, yang dipengaruhi oleh berbagai faktor. Faktor - faktor tersebut antara lain : relokasi kerja untuk peningkatan karir, dukungan organisasi terhadap kebijakan relokasi, lokasi kantor, dukungan keluarga, dan kehidupan sosial pegawai. (2) kepuasan kerja sebagai variabel dependen, dalam hal ini tingkat kepuasan pegawai pada posisi mereka saat ini dalam dunia kerja. Semua variabel-variabel yang digunakan tersebut berdasarkan penelitian - penelitian terdahulu dan telah teruji untuk mewakili dan menggambarkan penelitian atas topik serupa.

\subsection{Relokasi kerja (mutasi)}

Menurut Ericson dan Ortega (2006), terdapat tiga alasan utama mengapa sebuah organisasi memutuskan untuk melaksanakan kebijakan mutasi bagi para pegawainya. Pertama, Mutasi sebagai media pembelajaran para pegawai. Organisasi yang menjalankan kebijakan mutasi berharap agar para pegawainya dapat lebih mumpuni dalam banyak hal serta memiliki kapabilitas yang lebih apabila mereka sering berpindah dari satu tempat ke tempat lain, atau satu posisi ke posisi lain karena beragam pengalaman tersebut dapat membentuk mental serta meningkatkan wawasan mereka akan banyak hal. Lebih lanjut, dengan sering dimutasi, para pegawai akan memiliki wawasan yang lebih luas, tidak hanya dari sisi pekerjaan dan organisasi, tetapi juga wawasan mengenai lingkungan dan masyarakat sekitar.

Kedua, "Sarana pembelajaran bagi atasan". Hal ini berarti bahwa kebijakan mutasi pegawai dengan memindahkan para pegawai dari satu tempat ke tempat lainnya atau satu posisi jabatan ke posisi lainnya secara periodik, atasan dapat mempelajari kelebihan dan kekurangan dari bawahannya. Kemudian, relokasi atau rotasi jabatan dapat memberikan gambaran yang lebih jelas dan komprehensif mengenai kemampuan pegawai dalam jabatan tertentu dan spesialisasi yang dimilikinya. Lebih lanjut lagi, Ortega (2000) menyatakan bahwa rotasi pekerjaan dapat memudahkan para atasan untuk mengetahui pegawai yang kira-kira cocok untuk menempati posisi atau jabatan tertentu serta parameter keahlian yang perlu dimiliki agar seorang pegawai dapat menunjukkan kinerja terbaik mereka. Landau, Shamir dan Arthur (1992) menegaskan bahwa implementasi relokasi dapat memberikan manfaat dalam bentuk "mempertahankan formasi pegawai yang sesuai, mencegah pengurangan pegawai (bagi swasta), dan mengembangkan pengelolaan pegawai." (hal. 667).

Alasan ketiga yang dikemukakan oleh Erocson dan Ortega (2006) terkait kebijakan mutasi adalah berupa "sarana motivasi bagi pegawai". Dalam sudut pandang ketiga ini, rotasi kerja merupakan salah satu cara dalam rangka membuat kondisi lingkungan pekerjaan yang lebih menyenangkan bagi para pegawai. Dengan kata lain, rotasi dan relokasi bisa menjadi alat penyegaran dan menghilangkan kejenuhan akan rutinitas pekerjaan sehari-hari.

Penelitian ini menggunakan istilah "mutasi" berdasarkan pada Peraturan Menteri Keuangan nomor 39 Tahun 2009. Disebutkan bahwa relokasi kerja atau "mutasi" adalah perpindahan lokasi pegawai dengan mempertimbangkan posisi pekerjaan dan karir sesuai pola mutasi dan kebutuhan organisasi. Dengan kata lain, DJPb dapat menugaskan para pegawainya untuk pindah dari satu kantor ke kantor lainnya pada wilayah yang berbeda secara periodik. Definisi ini sesuai dengan formula Pinder dan Walter (1984) yang menyatakan bahwa relokasi atau rotasi kerja dapat diartikan sebagai "penugasan ulang secara permanen yang meliputi perpindahan pegawai dalam lingkup satu organisasi dari satu lokasi operasi (kantor) ke lokasi kantor lainnya" (hal. 188). Pola relokasi mengikuti kebutuhan dan prioritas organisasi dengan mempertimbangkan komposisi dan kapasitas formasi masing-masing kantor.

Singkatnya, dalam pelaksanaan kebijakan relokasi, para pegawai ditugaskan ulang ke lokasi kantor yang berbeda, tetapi tetap dalam tingkatan dan posisi jabatan yang sama. Hal ini bukan hanya dalam rangka memenuhi kebutuhan organisasi, tetapi juga diharapkan bisa memberikan manfaat bagi pegawai. Definisi mutasi dalam penelitian ini lebih fokus pada perubahan lokasi geografis para pegawai, bukan perubahan posisi jabatan dan pekerjaan. 


\subsection{Kepuasan Kerja}

Terdapat banyak penelitian mengenai kepuasan kerja karena hal tersebut merupakan salah satu faktor penting dalam strategi pengelolaan SDM. Dengan demikian, banyak pengertian yang berbeda-beda mengenai "kepuasan kerja". Locke (1969) menjelaskan bahwa kepuasan kerja adalah "keadaan emosi yang positif atau rasa puas terhadap suatu pekerjaan atas pencapaian, atau sarana dalam mempermudah pencapaian, nilai pekerjaannya tersebut" (hal. 136). Kemudian, terdapat tiga kondisi atau aspek yang mempengaruhi kepuasan kerja seseorang, antara lain : persepsi terhadap beberapa aspek terkait pekerjaan itu sendiri, standar nilai baik tertulis maupun tidak tertulis, dan penilaian terhadap hubungan antara persepsi kinerja dan nilai seseorang, baik disadari atau tidak. Bagaimanapun, Levering (1988) berpendapat bahwa kita perlu mempertimbangkan bahwa setiap individu memiliki karakteristik masing-masing; sehingga, perlu memperhatikan kondisi emosi masing-masing pegawai mengingat setiap individu tidaklah serupa dan tidak bisa diperlakukan serupa serta memiliki kemampuan untuk belajar serta tingkat kematangan emosi yang berbeda pula. Lebih lanjut, Landy dan Trumbo (1980) menambahkan bahwa pertanyaan yang utama dalam mengidentifikasi kepuasan kerja adalah dengan mencoba mengetahui apakah kondisi pekerjaan mendorong munculnya feeling yang positif atau negatif.

Sisi lain juga dicermati oleh Dunham (1984), yang menyatakan bahwa kepuasan kerja adalah "komponen afektif dari pekerjaan dan sikap terkait pekerjaannya tersebut" (hal. 40). Dengan demikian, "beberapa sisi atau faktor dapat mempengaruhi kepuasan kerja misalkan karakteristik pekerjaan, gaji atau penghasilan, atau rekan kerja." Kemudian, Lando dan Trumbo (1980) juga menyatakan bahwa sikap para pegawai dapat menggambarkan reaksi mereka atas kepuasan kerja.

\subsection{Pengembangan Hipotesis}

Penelitian ini dilaksanakan guna mengukur pengaruh kebijakan relokasi (mutasi) terhadap kepuasan pegawai dengan memperhatikan beberapa faktor terkait mutasi antara lain :

\subsubsection{Karir dan Kepuasan Kerja}

Dunham (1984) berpendapat bahwa kemungkinan seorang pegawai untuk dipromosikan ke posisi yang lebih tinggi dalam suatu organisasi dapat mempengaruhi tingkat kepuasan pegawai tersebut. Sesuai pendapat Morris (1956), pendapat ini memberikan kepercayaan umum bahwa dengan mengikuti dan mematuhi aturan dan kebijakan organisasi, pada akhirnya seorang pegawai dapat dipromosikan.
Dessler (2003) juga menambahkan bahwa kebijakan relokasi seharusnya dipandang sebagai kesempatan para pegawai untuk lebih meningkatkan pemahaman mereka akan organisasi lebih jauh, serta dalam rangka meningkatkan kapasitas, pengetahuan, dan kapabilitas mereka. Mereka dapat mempelajari strategi dan informasi yang dibutuhkan dalam rangka bertindak secara tepat agar karir dan posisi mereka bisa meningkat.

Di sisi lain, Landau, Shamir dan Arthur (1992) berpendapat bahwa menolak penugasan atau mutasi ke tempat yang baru dapat berpengaruh buruk terhadap peningkatan karir pegawai di masa depan.

Berdasarkan pembahasan di atas, dapat disimpulkan dalam hipotesis sebagai berikut :

Hipotesis 1 : Pegawai yang meyakini bahwa menerima kebijakan mutasi dapat meningkatkan karir mereka di masa depan, akan lebih puas dengan pekerjaan mereka.

\subsubsection{Dukungan Organisasi Terkait Kebijakan Relokasi dan Kepuasan Kerja}

'Gould dan Penley (1985) memaparkan bahwa seorang pegawai yang memiliki penghasilan di atas rata-rata dapat memiliki pengaruh yang positif dengan kesiapan pegawai untuk dimutasi, hal ini disebabkan oleh dua hal, antara lain : "1) seorang pegawai dengan penghasilan lebih tinggi dapat lebih menerima kesempatan relokasi dibanding para pegawai dengan penghasilan lebih rendah, dan 2) relokasi menyangkut beberapa tingkat risiko finansial." Lebih jauh lagi, pada suatu organisasi, pegawai dengan posisi jabatan yang tinggi menerima kompensasi lebih banyak serta dukungan dari organisasi dalam bentuk perumahan dan biaya pindah atau transportasi dibanding pegawai dengan jabatan lebih rendah atau pegawai yang tidak memiliki jabatan.

Organisasi selayaknya menimbang untuk memberikan lebih banyak kompensasi atau bayaran yang lebih tinggi untuk menarik minat para pegawainya; dengan demikian, dengan memberikan motivasi dan insentif yang lebih agar mereka lebih puas dalam menerima dan melaksanakan kebijakan relokasi tersebut (Wheeler dan Miller, 1990). Dalam penelitian ini, dukungan organisasi juga tidak hanya dalam bentuk kompensasi atau pembayaran, tetapi juga berupa fasilitas, dukungan rekan kerja, dan informasi yang memadai mengenai pelaksanaan kebijakan relokasi atau mutasi.

Berdasarkan pembahasan di atas, dapat disimpulkan dalam hipotesis sebagai berikut : Hipotesis 2 : Para pegawai yang menerima kompensasi dan dukungan yang memadai terkait mutasi akan lebih puas dengan pekerjaan mereka. 


\subsubsection{Lokasi Kantor dan Kepuasan Kerja}

Setiap pegawai memiliki preferensi lokasi masing-masing sesuai keinginan dan kebutuhan mereka. Preferensi lokasi ini tidak hanya terkait dengan kemudahan akses ke kampung halaman, tetapi juga apakah di tempat tersebut bisa menyediakan kemudahan dan kesempatan untuk peningkatan kemampuan, menyediakan tantangan, sesuai harapan akan pencapaian tujuan, dan otonomi (Noe, Steffy dan Barber, 1988). Sebagaimana disampaikan oleh Veiga (1983), keinginan untuk pindah secara signifikan dipengaruhi oleh kepuasan dalam melaksanakan pekerjaan pegawai itu sendiri. Dengan kata lain, apabila tempat kerja yang baru tidak dapat memberikan kenyamanan atau menyediakan halhal yang disebutkan di atas, pegawai akan segan untuk pindah. atas yakni :

Hipotesis yang sesuai dengan bahasan di

Hipotesis 3 : Para pegawai yang ditempatkan sesuai dengan preferensinya akan lebih puas dengan pekerjaan mereka.

\subsubsection{Dukungan Keluarga dan Kepuasan Kerja}

Banyak peneliti telah mempelajari dan mengukur sejauh mana pengaruh pasangan dari masing-masing pegawai terhadap kebijakan relokasi yang diterapkan terhadap pegawai tersebut, termasuk pengaruh terhadap keputusan untuk menerima penugasan ke tempat kerja yang baru (pindah lokasi) atau menerima relokasi (Bret, dkk, 1993). Sebagai tambahan, Bret dan Reilly (1988) menemukan bahwa pegawai yang telah berkeluarga lebih cenderung untuk menerima penugasan ke tempat kerja yang baru apabila didampingi keluarga. Selanjutnya, Araji (1983) juga menyatakan bahwa dukungan dari keluarga dan pasangan pegawai memiliki efek yang positif terhadap kesediaan menerima kebijakan relokasi kerja.

Oleh karena itu, sesuai dengan bahasan di atas, hipotesis yang diajukan sebagai berikut:

Hipotesis 4: Para pegawai yang mendapat dukungan dari keluarga, terkait kebijakan mutasi, akan lebih puas terhadap pekerjaan mereka.

\subsubsection{Kemampuan Sosialkultural, Komunitas, dan Kepuasan Kerja}

Terkait dengan kehidupan sosial dari para pegawai, Gould dan Penley (1985) serta Noe dkk (1988) menemukan hubungan yang negatif antara community tenure, jangka waktu seseorang hidup dalam komunitas atau masyarakat tertentu, dengan kesediaan pegawai tersebut untuk menerima penugasan ke tempat baru. Dengan kata lain, sebagaimana pendapat Fisher dan Shaw (1994), semakin lama seorang pegawai tinggal pada tatanan masyarakat tertentu di daerahnya, sehingga telah menyatu dengan masyarakat serta memiliki hubungan yang baik dengan komunitas di daerahnya tersebut, semakin kecil kemungkinan dia akan menerima penugasan untuk pindah atau puas dengan kebijakan tersebut.

Kemudian, Michelson menambahkan bahwa adat istiadat atau nilai - nilai sosial dari suatu lingkungan masyarakat seharusnya menjadi pertimbangan dalam pengambilan keputusan kebijakan relokasi, karena memindahkan seorang pegawai dari suatu tempat ke tempat lainnya tidak hanya berpindah kantor, tetapi juga pindah dari satu tatanan masyarakat ke tatanan masyarakat lainnya yang berbeda dengan latar belakang pegawai tersebut.

Sebagian besar pegawai yang tidak puas dengan pekerjaan mereka di tempat baru biasanya mereka yang tidak mampu menempatkan diri dan beradaptasi dengan baik dengan lingkungannya atau memiliki hubungan dan ikatan dengan masyarakat sehingga merasa terkucil di tempat baru (Herzberg dkk, 1987).

Oleh karena itu, sesuai bahasan di atas, hipotesis yang dibangun sebagai berikut :

Hipotesis 5 : Para pegawai yang memiliki kemampuan untuk menyesuaikan diri serta membangun hubungan dengan lingkungan yang baru akan lebih puas dengan pekerjaan mereka.

\subsubsection{Variable Kontrol dan Kepuasan Kerja}

Pada penelitian ini, kami juga mempertimbangkan beberapa variable kontrol yang dapat mempengaruhi kepuasan kerja seorang pegawai selain dari variable independen yang disebutkan. Variable kontrol yang menjadi pertimbangan antara lain usia, jenis kelamin, status pernikahan, tingkat pendidikan, masa kerja serta pengalaman mutasi. Variabel-variabel kontrol tersebut menjadi pertimbangan sesuai dengan penelitian-penelitian terdahulu.

Beberapa bukti empiris menunjukan bahwa pegawai yang lebih muda akan lebih menerima kebijakan relokasi (Stroh. 1999). Dalam hal jenis kelamin, Brett dan Stroh (1995) berpendapat bahwa wanita cenderung tidak puas apabila mereka dipindahkan mengingat potensi konflik atau pertimbangan keluarga yang muncul akan lebih besar daripada pegawai pria apabila dipindahkan.

Menurut pendapat Noe, Steffy, dan Barber (1998), status pernikahan pegawai juga memiliki pengaruh terhadap kesediaan untuk pindah, walaupun memang pengaruhnya tidak begitu kuat, apalagi bagi pegawai pria. Dari sisi tingkat pendidikan, tidak banyak bukti empiris yang menyebutkan adanya hubungan antara tingkat 
pendidikan dengan kepuasan terhadap kebijakan relokasi. Namun, Bret dan Reilly (1988) menemukan bahwa banyak pegawai yang dialihtugaskan memiliki tingkat pendidikan yang lebih tinggi dibanding mereka yang tidak direlokasi.

Dalam hal masa kerja dan pengalaman relokasi, Jan dan Frazer-Jans (2004) menyatakan bahwa para pegawai yang memiliki pengalaman kerja lebih banyak pada posisi tertentu akan lebih capable pada bidangnya tersebut, hingga mereka dipindahkan ke tempat dan posisi yang baru. Dengan kata lain, masa kerja tidak hanya memiliki pengaruh terhadap kinerja, tetapi juga memiliki pengaruh yang cukup signifikan terhadap kepuasan kerja di tempatnya saat ini. Namun, pada dasarnya banyak pegawai baru yang masih muda yang sering dipindahkan dari satu tempat ke tempat lainnya, diharapkan dengan demikian mereka mendapatkan pengalaman dan wawasan lebih (Jan dan Frazer-Jans, 2004). Selain itu, Pinder dan Schroeder (1987) juga menyinggung kemungkinan pengaruh dari pengalaman mutasi terdahulu dengan sikap dan kemampuan adaptasi pegawai terhadap kebijakan mutasi.

\section{METODOLOGI PENELITIAN}

Tujuan penelitian ini adalah untuk mengukur pengaruh kebijakan relokasi / mutasi terhadap kepuasan pegawai negeri sipil dengan mengambil sampel terhadap para pegawai Direktorat Jenderal Perbendaharaan, Kementerian Keuangan Republik Indonesia.

\subsection{Metode Pengambilan Sample}

Data dikumpulkan dengan mengirimkan kuisioner elektronik ke 334 target responden pada $\mathrm{DJPb}$. Setelah mendapatkan persetujuan dan dukungan instansi untuk mengadakan penelitian di lingkungan $\mathrm{DJPb}$, surat permintaan untuk berpartisipasi dikirimkan ke semua Kantor Wilayah Direktorat Jenderal Perbendaharaan di daerah untuk kemudian diteruskan kepada kantor - kantor unit vertikal di daerah untuk menugaskan para pegawai yang memiliki kriteria dan bersedia menjadi responden penelitian ini. Setelah kantorkantor vertikal mengirimkan nama-nama serta link email pegawai yang bersedia menjadi responden, penulis mendistribusikan link kuisioner langsung ke email dimaksud. Secara total, dikirimkan kepada para responden pada 3 Direktorat di Kantor Pusat, 13 Kantor Wilayah, dan 80 KPPN. Semua responden yang terpilih dapat menggambarkan komposisi para responden yang pembagian utamanya berdasarkan lokasi kantor.

Para sampel pada penelitian ini harus memenuhi berbagai kriteria, antara lain : (1) Merupakan pegawai yang menjadi target kebijakan relokasi, biasanya lulusan sekolah khusus
Kementerian Keuangan (Poltek Keuangan Negara/STAN) atau dari penerimaan S1 Umum; (2) Pernah dimutasi atau dipindahkan; dan/atau (3) Lokasi kantor saat ini jauh dari homebase. Pada umumnya, metode pengambilan sample pada penelitian ini menggunakan metode purposive sampling dengan membagi sampel berdasarkan lokasi sebagai kategori utama, yakni lokasi di Pulau Jawa-Bali serta Luar Jawa. Lebih lanjut, dari masing-masing kategori tersebut, penulis memilih responden dari lokasi-lokasi yang dapat merepresentasikan variasi sampel misalnya kota besar/ibu kota, kota kecil, atau daerah terpencil (remote area).

Sesuai dengan pendapat Krecjie dan Morgan (1970), dalam menentukan ukuran sampel yang diambil dari jumlah populasi, kita perlu menentukan tingkat kepercayaan (degree of confidence level). Pada penelitian ini, penulis menetapkan alpha $(\alpha)=0.5$ (tingkat kepercayaan 95\%). Lebih lanjut, sesuai tabel dari Krecjie dan Morgan, dari jumlah populasi $\mathrm{N}=6000$, minimum sampel yang diperlukan adalah 329; namun, pada penelitian ini penulis menambahkan target responden menjadi 334 orang responden. Dari 334 orang responden yang telah dikirim kuisioner, 178 kuisioner yang bisa dijadikan bahan untuk penelitian ini.

\subsection{Pertanyaan Kuisioner}

Pertanyaan-pertanyaan untuk survei ini menggunakan tiga instrumen utama yaitu : (1) Pertanyaan umum, yaitu pertanyaan-pertanyaan umum untuk menggambarkan keadaan demografis responden; (2) pertanyaan-pertanyaan mengenai kepuasan kerja; serta (3) pertanyaan-pertanyaan terkait aspek-aspek yang berhubungan dengan kebijakan relokasi, yang dibagi menjadi 5 (lima) faktor yaitu : karir, akses (lokasi), dukungan organisasi, keluarga, dan kultur sosial.

Pertanyaan-pertanyaan umum yang digunakan sebagai variabel kontrol terdiri dari beberapa item, antara lain : lokasi kantor, posisi jabatan, pangkat/golongan, jenis kelamin, tingkat pendidikan, usia, status pernikahan, status pekerjaan pasangan, masa kerja dalam organisasi, masa kerja pada lokasi kantor saat ini, dan pengalaman mutasi. Pertanyaan-pertanyaan tersebut dalam rangka memberikan gambaran yang komprehensif mengenai kondisi karir/pekerjaan dan keluarga serta pengalaman mutasi para responden. Pilihan jawaban diberikan kode tertentu. Sebagai contoh, untuk pertanyaan lokasi (Jawa dan bukan Jawa) diberikan kode "0" untuk Pulau Jawa-Bali dan "1" untuk luar Jawa-Bali. Untuk tingkat pendidikan, misalnya, " 1 " untuk lulusan SMA, "2" untuk D3, "3" untuk Sarjana/D4, "4" untuk S2/Master, "5" untuk S3/Doktor/Ph.D. 
Variabel berikutnya mengenai pertanyaanpertanyaan terkait kepuasan kerja. Pertanyaanpertanyaan menggunakan metode skala Likert dengan 5 (lima) tingkatan jawaban (1 = Sangat Setuju hingga 5 = Sangat tidak setuju). Pertanyaanpertanyaan yang digunakan dalam rangka mengumpulkan informasi mengenai tingkat kepuasan pegawai dalam pekerjaan mereka. Pertanyaan - pertanyaan dalam bagian kedua ini meliputi 9 (sembilan) dimensi utama pada pengukuran persepsi atas kepuasan kerja, yaitu : penghasilan, kenaikan pangkat, pengawasan, penghargaan, tata kerja, rekan kerja, komunikasi, dan budaya kerja.

Bagian terakhir adalah pertanyaan-pertanyaan mengenai 5 faktor yang berkaitan erat dengan kebijakan mutasi. Kelima kategori tersebut dapat menggambarkan aspek-aspek apa saja yang terkait dengan kehidupan pegawai manakala mereka dipindahtugaskan dari lokasi satu ke lokasi lainnya (Stroh, 1999). Kategori atau aspek-aspek tersebut antara lain : karir di masa depan, dukungan organisasi dalam kebijakan mutasi, akses pada kampung halaman/preferensi lokasi), dukungan keluarga, dan kompetensi sosialkultural. Dalam bagian ketiga ini juga menggunakan skala Likert namun dengan pilihan 7 (tujuh) tingkatan jawaban. Hal ini agar para responden memiliki jangkauan respon pilihan yang lebih luas ( 1 = Sangat Setuju hingga 7 = Sangat tidak setuju) .

Sebagai tambahan, semua pertanyaan yang digunakan dalam penelitian ini berdasarkan beberapa penelitian terdahulu yang berbahasa Inggris. Oleh karena itu, pertanyaan-pertanyaan yang diajukan harus dialihbahasakan terlebih dahulu ke dalam bahasa Indonesia. Dalam rangka meneliti apakah pertanyaan-pertanyaan yang akan diajukan telah sesuai dengan tujuan yang diinginkan serta dapat dipahami dengan baik oleh calon responden, penulis meminta beberapa orang yang memiliki kemampuan dua bahasa yang baik (Indonesia - Inggris) untuk mengidentifikasi dan mengevaluasi setiap pertanyaan, baik alih bahasa dari bahasa Inggris ke bahasa Indonesia maupun sebaliknya. Hal ini dilakukan agar pertanyaanpertanyaan tersebut dapat dipercaya dan dipahami dan tidak melenceng jauh dari teks aslinya pada penelitian terdahulu yang berbahasa asing. Umpan balik atas kualitas dan kelayakan setiap pertanyaan dilakukan sebelum survei benar-benar dilaksanakan.

\subsection{Analisis Data}

Dari total 334 kuisioner yang dibagikan kepada target reponden, terdapat 178 sampel yang benar-benar bisa digunakan. Dengan demikian, rata-rata respons dari responden sebesat 53.3\%. Bagian pertama kuisioner yang berisi pertanyaan- pertanyaan mengenai variabel demografi, dapat digambarkan dalam tabel 1.

Tabel 1 menunjukkan kondisi demografi yang berkaitan dengan kebijakan relokasi. Lokasi responden sebagian besar dari luar Jawa-Bali $(62,1 \%)$. Sebagai tambahan, perbedaan responden pria dan wanita juga cukup signifikan. Responden pria mencapai $84,2 \%$ karena para pegawai yang ditempatkan jauh dari homebase, sesuai kriteria penelitian ini, rata-rata adalah pegawai pria. Pada dasarnya, pegawai wanita memiliki keuntungan karena bisa memilih lokasi penempatan yang lebih dekat dengan keluarga atau homebase atau dalam rangka ikut suami. Lebih lanjut, usia responden penelitian ini sebagian besar pada rentang usia 31 s.d. 40 tahun $(41,8 \%)$. Pada tahapan usia ini, pada umumnya para pegawai yang menjadi responden telah mencapai golongan III, sekitar 68,9\% responden.

\subsection{Tes Uji Kelayakan}

Pertanyaan-pertanyaan pada kuisioner ini terdiri dari beberapa set pertanyaan. Dalam rangka mengukur keandalan dan validitas dari pertanyaan-pertanyaan tersebut, diperlukan tes permulaan. Sebagaimana yang dikemukakan oleh Gliem dan Gliem (2003), untuk mengukur keandalan pertanyaan pada kuisioner survei yang menggunakan skala Likert, sangatlah penting untuk dilakukan pengukuran terhadap koefisien Cronbach Alpha yang bisa menggambarkan konsistensi set kuisioner tersebut (hal. 88). Hasil uji kelayakan pada tabel 2 .

Tabel alpha menunjukkan bahwa semua set pertanyaan secara statistik andal dan dapat diterima. Cronbach (2004) menyatakan bahwa nilai alpha di atas 0.7 menunjukkan bahwa set pertanyaan yang diajukan pada survei konsisten dan dapat diandalkan, semakin mendekati nilai 1 semakin baik. Akan tetapi, dari variabel-variabel di atas, pertanyaan mengenai preferensi lokasi dan dukungan keluarga agak diragukan karena memiliki nilai alpha di bawah 0,7. Walaupun Cronbach (2004) juga menambahkan, selama nilai alpha masih di atas 0,6 masih bisa diterima. Selain keandalan dan validitas pertanyaan, tes berikutnya juga dilakukan terhadap hubungan antar variabel dengan adanya Correlation test.

\subsection{Tes Korelasi}

Tabel 3 menunjukkan hubungan antara kelima faktor persepsi pegawai terkait kebijakan relokasi dengan kepuasan kerja, nilai-nilai tersebut didapatkan dengan menggunakan Pearson Correlation test di antara variabel-variabel tersebut. Hasil tes menunjukkan bahwa kepuasan kerja memiliki hubungan yang positif dan secara statistik signifikan terhadap dukungan organisasi $(\mathrm{r}=0.419, \mathrm{p}<0.01)$. Kepuasan kerja juga memiliki 
hubungan positif dan signifikan dengan preferensi lokasi ( $\mathrm{r}=0.28, \mathrm{p}<0.01)$ dan kemampuan kultur sosial para pegawai $(\mathrm{r}=0.328, \mathrm{p}<0.01)$. Yang cukup mengejutkan, karir di masa depan serta dukungan keluarga secara statistik tidak memiliki hubungan dengan tingkat kepuasan kerja pegawai.

Maka, didapatkan bahwa terkait dengan persepsi atas kebijakan relokasi (mutasi), hanya dukungan organisasi, lokasi, dan sosialkultural dari pegawai yang memiliki hubungan tingkat kepuasan. Walaupun pada titik ini belum diketahui variabel atau aspek mana yang mempengaruhi, apakah dari ketiga aspek tersebut terhadap kepuasan kerja atau sebaliknya atau dua arah. Oleh karena itu, diperlukan regresi untuk mengetahui lebih jauh faktor mana yang benar-benar berpengaruh terhadap kepuasan kerja pegawai.

\subsection{Hasil Regresi}

Untuk menjelaskan hubungan antara variabel independen dan variabel dependen, digunakan regresi OLS. Mengingat variabel demografi yang digunakan sebagai variabel kontrol merupakan categorical variables, perlu diubah ke dalam bentuk dummy agar bisa mewakili masing-masing kategori. Setelah itu, langkah selanjutnya adalah menjalankan regresi dengan memasukkan keenam aspek yang diteliti. Nilai yang dimasukkan ke dalam persamaan berdasarkan nilai rata-rata dari hasil kategori masig-masing, baik nilai rata-rata untuk pertanyaan mengenai kepuasan kinerja (Likert Scale dengan skala 1 s.d. 5) maupun oleh masing-masing aspek terkait relokasi kerja (Likert Scale dengan skala 1 s.d. 7).

Sebagaimana yang ditunjukkan oleh variabel hasil regresi (tabel 4), kepuasan kerja sebagai variabel dependen dapat dijelaskan oleh model dengan $F=2,45, p<0,01$. Nilai koefisien yang terdapat pada tabel dimaksud adalah nilai nominal.

\section{HASIL PENELITIAN DAN DISKUSI}

Hipotesis 1 memprediksi bahwa pegawai yang meyakini bahwa relokasi kerja dapat memberikan dampak yang positif terhadap karir di masa depan akan lebih puas dengan pekerjaannya. Akan tetapi, baik dari tes korelasi maupun regresi tidak memberikan hasil yang signifikan bahwa karir di masa depan berpengaruh atau paling tidak memiliki korelasi dengan kepuasan kerja $(\beta=-$ 0.012, $\mathrm{p}>0.1)$ dan $(\mathrm{r}=0.106, \mathrm{p}>0.1)$. Dengan demikian, Hipotesis 1 tidak diterima.

Hipotesis 2 memprediksi bahwa para pegawai yang mendapat dukungan organisasi yang memadai terkait kebijakan relokasi kerja akan lebih puas dengan pekerjaannya. Dari hasil analisis hubungan antar variabel, didapatkan bahwa dukungan organisasi memiliki hubungan yang kuat dengan kepuasan kerja $(r=0.419, \mathrm{p}<0.01)$. Selain itu, hasil tes regresi juga menunjukkan bahwa dukungan organisasi secara statistik signifikan memiliki pengaruh yang positif terhadap kepuasan kerja $(\beta=0.129, \quad p<0.01)$. Dengan demikian, hipotesis 2 dapat diterima.

Hipotesis 3 memperkirakan bahwa para pegawai yang ditugaskan di lokasi yang sesuai keinginan akan lebih puas dengan pekerjaan mereka. Dari hasil tes korelasi menunjukkan bahwa kedua variabel berhubungan secara statistik dan signifikan $(\mathrm{r}=0.28, \mathrm{p}<0.01)$. Demikian pula dengan hasil regresi $(\beta=0.67, p<0.1)$ bahwa preferensi dapat berpengaruh terhadap kepuasan kerja. Walaupun, secara statistik tidak begitu signifikan mengingat alpha $\alpha$ yang cukup besar $(\mathrm{p}<$ 0,1 ). Dari hasil tersebut dapat disimpulkan bahwa Hipotesis 3 juga dapat diterima.

Hipotesis 4 memprediksi pegawai yang mendapat dukungan keluarga dalam menjalani mutasi akan lebih puas dengan pekerjaannya. Untuk aspek ini, baik hasil tes korelasi maupun regresi menunjukkan bahwa secara statistik tidak ada korelasi antara dukungan keluarga dan kepuasan kerja. Selain itu, dukungan keluarga tidak berpengaruh terhadap tingkat kepuasan kerja pegawai. Oleh karena itu, Hipotesis 4 tidak dapat diterima.

Hipotesis 5 menyatakan bahwa para pegawai yang memiliki kemampuan untuk beradaptasi dan membangun ikatan dengan lingkungannya akan lebih puas dengan pekerjaannya. Hasil korelasi menunjukkan bahwa terdapat hubungan yang positif dan signifikan antar kedua variabel $(\mathrm{r}=0.3276, \mathrm{p}<0.01)$. Hal ini menunjukkan bahwa semakin besar kapasitas pegawai dan semakin kuat ikatan dengan komunitas dan masyarakat sekitar, tingkat kepuasan pegawai akan lebih tinggi. Sama halnya dengan hasil regresi, bahwa kemampuan kultur sosial berpengaruh terhadap tingkat kepuasan pegawai secara positif dan signifikan $(\beta=0.069, p<0.1)$. Dengan kata lain, temuan ini mendukung Hipotesis 5.

\subsection{Diskusi}

Hasil regresi menunjukkan bahwa kepuasan kerja tidak dipengaruhi oleh persepsi bahwa dengan mengikuti kebijakan mutasi, karir pegawai dapat meningkat. Dengan kata lain, para pegawai kurang meyakini bahwa kebijakan mutasi memberi dampak positif dalam pekerjaan mereka. Jika kita menelaah salah satu poin yang ditanyakan dalam persepsi kepuasan kerja, pertanyaan "Saya memiliki kesempatan yang lebih kecil untuk dipromosikan". hanya $35,6 \%$ yang menjawab sangat tidak setuju atau tidak setuju dengan pernyataan tersebut. Dengan demikian, 64,6\% responden meragukan bahwa mereka memiliki kesempatan untuk naik jabatan di masa depan. Lebih lanjut, walaupun mungkin para pegawai 
memiliki tambahan wawasan dan pengetahuan apabila direlokasi, hal tersebut tidak memberikan manfaat yang kongkrit terhadap karir mereka. Sebagai tambahan, dalam kasus ini, dapat disimpulkan bahwa kebijakan relokasi hanya terkait perubahan lokasi, bukan perubahan tanggung jawab. Dengan kata lain, tempat kerja mungkin berbeda, tetapi posisi dan tanggungjawab secara umum sama.

Menurut Noe, Steffy dan Barber (1988), dalam hal tingkatan karir, hanya para pegawai di bawah usia 30 tahun (trial stage) yang sepakat dan meyakini bahwa pelaksanaan kebijakan relokasi dapat berkontribusi dalam peningkatan karir. Dengan demikian, para pegawai yang lebih muda tersebut lebih siap untuk dipindahkan dalam rangka meningkatkan dan mengeksplorasi kapasitas mereka. Pada akhirnya, pengalaman dan pengetahuan ini dapat memberikan manfaat bagi karir mereka di masa depan. Sedangkan para pegawai pada rentang usia $31-41$ tahun(advanced stage) sebagian besar mulai memiliki posisi yang lebih mantap dan zona nyaman di dunia kerja. Begitu pula dengan pegawai di rentang usia 45 s.d. 65 tahun (maintenance stage) yang cenderung menghindari hambatan yang bersifat teknis. Kedua tingkatan usia tersebut lebih cenderung fokus kepada kehidupan keluarga dan kehidupan pribadi lainnya dibanding peningkatan karir (Schein, 1978, sebagaimana dikutip dalam Stroh, 1999). Oleh karena itu, jika melihat komposisi pegawai pada $\mathrm{DJPb}$ yang sebagian besar merupakan pegawai pada tingkatan usia advanced dan maintenance, persepsi bahwa kebijakan relokasi dapat memberi manfaat terhadap peningkatan karir tidaklah signifikan. Alasannya, persepsi tersebut lebih bisa diterima oleh pegawai usia muda.

Pada sisi lain, dukungan organisasi, yang di dalamnya termasuk variabel kompensasi dalam kebijakan relokasi, merupakan aspek yang sangat berpengaruh terhadap tingkat kepuasan pegawai. Para pegawai meyakini bahwa kompensasi yang lebih besar serta dukungan fasilitas yang memadai untuk bekerja di tempat baru, sebagai bentuk dukungan dari organisasi, dapat memberikan kepuasan yang lebih tinggi. Hal tersebut bisa dimaklumi karena Indonesia adalah negara yang sangat besar dan pelaksanaan kebijakan relokasi di $\mathrm{DJPb}$ meliputi jangkauan wilayah yang sangat luas. Oleh karena itu, diperlukan kompensasi serta dukungan organisasi terkait fasilitas dalam rangka pelaksanaan kebijakan mutasi. Selain itu, dukungan organisasi dalam bentuk transparansi informasi juga diperlukan.

Dari aspek preferensi lokasi juga menunjukkan bahwa lokasi berpengaruh terhadap kepuasan kerja pegawai, walaupun tidak begitu kuat seperti hasil pada tes korelasi. Penjelasan terkait hal tersebut bisa jadi pengaruh yang lebih kuat pada arah sebaliknya dimana kepuasan pegawai bekerja di suatu lokasi menjadikan lokasi kerjanya tersebut favorit baginya. Selain itu, mungkin ada faktor lain yang lebih penting bagi para pegawai dibanding dipindahkan ke lokasi yang diharapkan. Kemudian, jika menelaah kembali faktor lokasi sebagai kontrol variabel, para pegawai yang bekerja di pulau Jawa-Bali cenderung lebih puas dengan pekerjaannya.

Salah satu faktor yang tidak mendukung hipotesis yang dibangun di awal adalah hubungan antara dukungan keluarga dan kepuasan pegawai. Temuan ini menunjukkan bahwa para pegawai berpendapat bahwa pertimbangan keluarga tidak terlalu berpengaruh atas kepuasan di tempat kerja. Hal ini bisa terjadi karena sebagai pegawai negeri sipil, para pegawai harus tetap menjalani penugasan ke tempat baru walaupun jauh dari keluarga. Sama halnya dengan para pegawai senior yang anaknya telah memasuki usia sekolah yang cukup tinggi, sekolah menengah misalnya, biasanya mereka meninggalkan istri dan anak mereka mengingat sulitnya mengurus kepindahan sekolah. Selain itu, dukungan kompensasi dari organisasi juga belum mencakup biaya pindah sekolah atau dukungan dalam bentuk lain yang mempermudah orang tua dalam mengurus kepindahan sekolah anaknya. Masalah lain juga timbul ketika pasangan bekerja dan tidak bisa ditransfer ke tempat kerja yang sama dengan pegawai.

Terkait dengan kompetensi kultur sosial, sangatlah diperlukan kemampuan tersebut bagi para pegawai untuk beradaptasi dan bisa menempatkan diri ke dalam tatanan masyarakat yang baru. Apalagi, Indonesia terdiri atas kepulauan dan antar satu daerah dengan daerah lain memiliki latar belakang budaya yang sangat beragam. Rendahnya kapabilitas seorang pegawai dalam beradaptasi dengan lingkungan baru serta menyatu dengan lingkungan masyarakat yang berbeda dengan latar belakang si pegawai, dapat berujung pada ketidakpuasan dan perasaan yang tidak nyaman dan terkucilkan dalam pergaulan. Smith (1963, dalam Herzberg, 1987) menyatakan bahwa "orang-orang yang merasa tidak puas dengan pekerjaan mereka biasanya memang memiliki kesulitan untuk menyesuaikan diri dengan standar dan budaya kinerja di tempat kerja dan lingkungannya. Di sisi lain, mereka yang puas dengan pekerjaannya cenderung mudah beradaptasi dan lebih fleksibel" (hal. 19). Penelitian ini juga menunjukkan bahwa kemampuan beradaptasi dan menyesuaikan diri dengan lingkungan baru bisa berpengaruh terhadap kepuasan pegawai. Stroh (1998) juga menambahkan bahwa lokasi kantor yang disukai oleh para pegawai bisa jadi merupakan daerah yang memiliki latar belakang adat istiadat dan 
budaya yang memang sesuai dengan latar belakang dan budaya pegawai tersebut.

Terakhir, variabel kontrol yang juga dimasukkan ke dalam model penelitian ini memberikan hasil yang berbeda. Usia, menurut berbagai kategori, tidak berpengaruh terhadap tingkat kepuasan pegawai $(p>0,1)$. Sama halnya dengan jenis kelamin, yang secara statistik tidak signifikan berpengaruh terhadap kepuasan. Demikian pula status pernikahan yang tidak memiliki pengaruh terhadap kepuasan kerja. Hal ini sesuai dengan tidak diterimanya hipotesis yang menyatakan bahwa dukungan keluarga berpengaruh terhadap tingkat kepuasan. Sementara itu, variabel kontrol lain memiliki pengaruh terhadap kepuasan kerja, terutama dari sisi posisi jabatan dan lokasi. Dari hasil penelitian didapat bahwa pegawai dengan posisi jabatan lebih tinggi cenderung memiliki tingkat kepuasan kerja yang lebih tinggi, jika dikaitkan dengan dukungan organisasi, hal tersebut wajar mengingat para pejabat di DJPb mendapat fasilitas dan kompensasi yang lebih terkait kebijakan relokasi dibanding pelaksana. Selaras dengan variabel dukungan organisasi yang memiliki pengaruh yang signifikan terhadap kepuasan. Dalam hal jumlah atau pengalaman relokasi, semakin banyak pengalaman mutasi maka tingkat kepuasannya lebih tinggi. Hal ini bisa jadi karena semakin sering direlokasi, kemampuan pegawai untuk beradaptasi lebih tinggi.

\section{KESIMPULAN DAN SARAN}

Dari hasil penelitian didapat 3 (tiga) poin penting terkait kebijakan relokasi yang dapat mempengaruhi kepuasan pegawai, antara lain: dukungan organisasi, preferensi lokasi, dan kemampuan kultur sosial pegawai. Dukungan organisasi bisa dalam bentuk kompensasi, transparansi, maupun dukungan rekan kerja. Menurut Wheelere dan Miller (1990), kompensasi yang lebih diperlukan dalam rangka memberikan motivasi terhadap para pegawai yang direlokasi.

Hal penting lainnya adalah kemampuan kultur sosial. Walaupun kemampuan tersebut berasal dari individu, organisasi dapat menggalakkan aktivitasaktivitas yang dapat menumbuhkan ikatan para pegawai satu sama lain, terutama para pegawai baru. Misalnya, ketika terjadi relokasi, dalam rangka menyambut pegawai baru, kantor dapat mengadakan acara outing, capacity building, atau family gathering. Selain dalam rangka membuat pegawai lama solid, sekaligus menumbuhkan semangat kebersamaan dengan pegawai baru. Sunseri (1991) menyatakan bahwa para pegawai baru seharusnya didorong untuk mengeksplorasi lingkungannya yang baru. Semakin pegawai tersebut mengetahui dan terbiasa dengan lingkungan barunya tersebut, akan semakin mudah bagi dirinya dan keluarga (jika pegawai tersebut membawanya) untuk beradaptasi dengan lingkungan (dikutip dari Stroh, 1990).

Mengingat cukup sedikit penelitian dengan topik serupa di Indonesia ataupun negara berkembang lainnya, diharapkan ke depan dilaksanakan penelitian serupa dengan beberapa pertimbangan, merujuk pada keterbatasanketerbatasan penelitian ini. Penelitian ini bersifat kognitif, oleh karena itu, perlu dibangun penelitian serupa, tetapi dengan pendekatan affirmative yang bisa memberikan perspektif yang lebih luas terhadap determinan dari kepuasan kerja. Selain itu, mungkin perlu ditambahkan aspek lain terkait kebijakan relokasi yang juga penting yakni prinsip keadilan dalam penerapan kebijakannya. Lebih lanjut, dalam meningkatkan rata-rata respons serta kualitas survei, beberapa metode layak digunakan termasuk metode wawancara yang bisa memberikan hasil analisis lebih dalam. Terakhir, penelitian serupa juga perlu memperhatikan variabel lain yang bisa mempengaruhi kepuasan kerja pegawai misalnya karakter dari pegawai itu sendiri.

\section{IMPLIKASI DAN KETERBATASAN PENELITIAN}

Hasil-hasil penelitian ini dapat menggambarkan kondisi pada DJPb. Apabila kita menelaah kondisi demografi pegawai DJPb secara keseluruhan serta hasil survei mengenai lokasi preferensi kantor yang diinginkan, bagian SDM perlu mengevaluasi pola kebijakan relokasi yang ada serta lebih mempertimbangkan dukungan organisasi yang lebih memadai.

Hasil penelitian mengindikasikan bahwa dukungan organisasi, baik berupa kompensasi maupun transparansi, adalah faktor yang paling berpengaruh terhadap tingkat kepuasan pegawai. Dalam hal ini, kita bisa menyebutnya sebagai faktor eskternal atau instrumental (Stroh, 1998). Variabel lain yang juga berpengaruh antara lain kemampuan kultur sosial pegawai yang diperlukan dalam rangka adaptasi dan menyesuaikan diri dengan lingkungan yang baru, baik lingkungan dan budaya di tempat kerja maupun di masyarakat, hal ini menjadi faktor internal pegawai. Abendroth dan Dulk (2015), dalam artikel mereka mengenai worklife balance, berpendapat bahwa dukungan instrumental dari organisasi dapat memberikan efek yang positif terhadap kepuasan pegawai apabila bagian SDM bukan hanya mengelola karir profesional pegawai, tetapi juga memperhatikan kehidupan pribadi mereka. Demikian halnya dengan transparansi dan keadilan dalam pelaksanaan pola relokasi, mengingat preferensi lokasi juga merupakan salah satu faktor yang berpengaruh terhadap kepuasan kerja. 
Oleh karena itu, DJPb selayaknya mempertimbangkan untuk memberikan dukungan baik berupa fasilitas serupa bagi para pegawai yang direlokasi terlepas dari posisi jabatannya, walaupun secara kualitas dan kuantitas tidaklah sama. Selain itu, diperlukan upaya untuk memberikan tambahan dukungan bagi pegawaipegawai baru agar bisa nyaman di tempat kerjanya yang baru dan lebih menyatu dengan masyarakat dan lingkungan sekitar apabila tempat kerjanya yang baru berbeda jauh dengan latar belakang pegawai. Di samping itu, mengingat preferensi lokasi juga salah satu variabel yang berpengaruh, memang cukup sulit jika semua pegawai dipindahkan sesuai keinginan mereka karena ada kebutuhan organisasi, tetapi paling tidak, prinsip keadilan serta transparansi informasi mengenai pola mutasi dapat membantu meningkatkan kepuasan para pegawai. Namun, jika kita melihat dari sisi keterbatasan anggaran, opsi lainnya adalah dibandingkan dengan memberikan kompensasi yang lebih, yang bisa membebani anggaran, akan lebih baik apabila bagian SDM mengevaluasi pola relokasi dan memformulasi pola baru yang lebih hemat baik dari sisi anggaran maupun pengeluaran pegawai dalam memenuhi kebutuhan pribadi.

Penelitian ini bertujuan untuk meneliti pengaruh kebijakan relokasi terhadap kepuasan kerja dengan memperhatikan beberapa aspek yang menggambarkan persepsi para pegawai terhadap hal-hal terkait kebijakan relokasi. Pada dasarnya, pengukuran dan evaluasi dari kemungkinan, kondisi atau outcome harus didefinisikan sebagai faktor kognitif kepuasan kerja (Moormon, 1993, dikutip Thompson dan Thua, 2016). Demikian pula faktor kognitif kepuasan kerja dapat diukur dengan memperhatikan dan menghitung remunerasi, kesempatan, dan beberapa tingkatan pekerjaan yang dapat dibedakan, yang dihitung secara komparatif satu sama lain (Locke, 1969).

Sebagai penelitian kognitif, sebuah survei seharusnya dapat menggambarkan kondisi sesungguhnya, termasuk keadaan emosi dan persepsi terhadap isu tertentu dari para pegawai. Akan tetapi, pertanyaan-pertanyaan pada penelitian ini mungkin belum mampu menggambarkan keadaan emosi dan persepsi para pegawai secara komprehensif. Selain itu, terdapat dua set pertanyaan yang memiliki nilai Cronbach alpha di bawah 0.7, walaupun masih dapat diterima, tetapi selayaknya dirumuskan pertanyaan yang lebih reliable agar lebih berkualitas.

Keterbatasan lain dari penelitian ini adalah metode pengumpulan data yang menggunakan media elektronik. Walaupun lebih nyaman dan mudah digunakan oleh peneliti, selain lebih irit waktu dan biaya, tetapi dari sisi respon penerima, kemungkinan response rate yang lebih besar bisa didapat apabila menggunakan dokumen tertulis. Walaupun memang, Cook, Heath dan Thompson (2000) menyatakan bahwa keterwakilan dari setiap kategori responden yang dituju lebih utama daripada jumlah responden itu sendiri.

Keterbatasan berikutnya terkait pemilihan data sampel. Para pegawai DJPb tersebar di berbagai daerah di seluruh provinsi. Namun, surat pengantar penelitian serta permohonan bantuan dari Sekretariat DJPb dengan nomor S6834/PB.1/2016 hanya ditujukan kepada kantorkantor wilayah. Setiap kantor wilayah kemudian diminta untuk menugaskan pegawai di lingkungan kerja mereka untuk berpartisipasi dalam penelitian ini. Mengingat tidak semua kantor wilayah meneruskan atau merespon surat pengantar tersebut, penulis meneruskan sendiri surat pengantar tersebut ke kantor - kantor unit di daerah. Hal ini diperlukan mengingat pentingnya faktor keterwakilan atas beberapa kategori dan latar belakang pegawai dalam survei ini.

Terakhir, keterbatasan penelitian ini adalah karena kekhususan tema itu sendiri. Penelitian ini mengukur persepsi para pegawai dari suatu organisasi terhadap kebijakan tertentu pada organisasinya. Pada kenyataannya, setiap organisasi memiliki karakter sendiri baik dalam pelaksanaan kebijakan maupun kondisi organisasi. Oleh karena itu, hasil yang berbeda pada tema serupa mungkin bisa didapat apabila penelitian dilaksanakan pada organisasi berbeda.

\section{DAFTAR PUSTAKA (REFERENCES)}

Anderson, J.C., Milkovich, G.T, \&Tsui, A. (1981). A model of intraorganizational mobility. Academy of Management Review, 6, 529538.

Araji, S. K. (1983). Married white women: Occupational mobility and earnings of part-time vs. full-time workers. Humboldt Journal of Social Relations, 10, 61 - 89.

Beauregard, T. A., \& Henry, L. C. (2009). Making the link between work-life balance practices and organizational performance. Human resource management review, 19(1), 9-22.

Brett, J.M., Stroh, L.K., Reilly, A.H. (1993). Pulling up roots in the 1990s: who's willing to relocate? Journal of Organizational Behavior, 14, 49-60.

Cook, C., Heath, F., \& Thompson, R. L. (2000). A meta-analysis of response rates in web-or internet-based surveys. Educational and psychological measurement, 60(6), 821836.

Cronbach, L. J., \&Shavelson, R. J. (2004). My current thoughts on coefficient alpha and successor procedures. Educational and 
psychological measurement, 64(3), 391418.

Dessler, G. (2003). Human Resources Management (9th edition). New Jersey. Prentice Hall.

Dubrin, A.J. (2004). Applying Psychology, individual and Organisational Effectiveness. New Jersey. Pearson Education, Inc.

Dunham, R.B. (1984). OrganizationalBehaviour. Illinois Richard D. Irwin, Inc.

Ericson, T., \& Ortega T. (2006). The adoption of Job rotation: testing the theories. Industrial and Labor Relations Review, 59, 653-666.

Fisher, C. D., \& Shaw, J. B. (1994). Relocation attitudes and adjustment: A longitudinal study. Journal of Organizational Behavior, $15,209-224$.

Gliem, A., \&Gliem, R (1986). Calculating, interpreting and reporting Cronbach's alpha reliability $2.02 \mathrm{y}$ coefficient for Likert-type scales. Midwest Research to Practice Conference in Adult, Continuing and Community Education, 2003 (pp. 8288).

Gould, S., \&Penley, L.E. (1985). A study of the correlates of the willingness to relocate. Academy of Management Journal, 28, 472478.

Herzberg, F., Mausner, B., Peterson, R.O., \&Capwell, D.F. (1987). Job Attitude: Review of research and opinion. Pittsburgh, Pennsylvania: Garland Publishing, Inc.

Javed, M., RifatBalouch, \& Fatima Hassan (2014). Determinants of Job Satisfaction and its impact on Employee Performance and Turnover Intentions. International Journal of Learning \& Development, 4 (2).

Jans, N., \& Frazer-Jans, J. (2004). Career development, job rotation, and professional performance. Armed Forces \& Society, 30(2), 255-277.

Koch, M. J., \&amp; McGrath, R. G. (1996). Improving labor productivity: Human resource management policies do matter. Strategic management journal, 17(5), 335-354.

Kirschenbaum, A. (1991). The corporate transfer: Origin and destination factors in the decision to change jobs. Journal of Vocational Behavior, 38, 107 \pm 123 .

Landau J, Hammer TH (1986). Clerical employees' perception of intraorganizational career opportunities. Academy of Management Journal, 29, 385-404

Landau, J. C., Shamir, B., \&amp; Arthur, M. B. (1992). Predictors of willingness to relocate for managerial and professional employees. Journal of Organizational Behavior, 13(7), 667-680.

Landy, F.J., \& Trumbo, D.A. (1980). Psychology of Work Behaviour, Illinois: The Dorsey Press.
Lee, T.W., \& Johnson, D. R. (1994). Reaction to job transfer by job type and career stage. Journal of Business and Psychology, 8, 377390.

Levering, R. (1988). A great Place to Work. New York: Random House, Inc. New York: Random House of Canada Limited, Toronto.

Locke, E. A. (1969). What is job satisfaction? Organizational behavior and human performance, 4(4), 309-336.

Mello, J.A (2006). Strategic Human Resource Management. Ohio: Thomson Corporation.

Morris, J.R (1956). Job rotation. Journal of Business, $29,268-273$

Michelson, G. (2000). Labor history and culture: An overview. Labor history 79, 1-10.

Noe, R. A., \&amp; Barber, A. E. (1993). Willingness to accept mobility opportunities: Destination makes a difference. Journal of Organizational Behavior, 14(2), 159-175.

Noe, R. A., Steffy, B. D., \&amp; Barber, A. E. (1988). An Investigation of the factors influencing employee willingness to accept mobility opportunities. Personnel Psychology, 41(3), 559-580.

Ortega, J. (2001). Job rotation as learning mechanism. Management science, 47, 1361-1370

Pinder, C., \& Schroeder, K. (1987). Time to proficiency following job transfer. Academic of Management Journal, 2, 336365.

Pinder, C., \& Walter, G. (1984). Personnel Transfer and employee development. Research in Personnel and Human Resources Management, 30, 187-218

Qu H., Xinyuan Zhao (2011). Employees' workfamily conflict moderating life and job satisfaction. Journal of Business Research,55 (2014), 22-28.

Rainey, H. G. (2010). Understanding and managing public organizations. John Wiley \& Sons.

Riemer, J. W. (2000). Job relocation, sources of stress, and sense of home. Community, Work \& Family, 3(2), 205-217.

Sell, R. R. (1983). Transferred jobs: A neglected aspect of migration and occupational change. Work and Occupations, 10(2), 179 206.

Stroh, L. K. (1999). Does relocation still benefit corporations and employees? An overview of the literature. Human resource management review, 9(3), 279-308.

Sunseri, A. J. (1991). How to reduce family relocation stress. Healthcare financial management: journal of the Healthcare Financial Management Association, 45(8), 92-92. 
Tavakol, M., \&Dennick, R. (2011). Making sense of Cronbach's alpha. International journal of medical education, 2, 53.

Thompson, E. R., \&Phua, F. T. (2012). A brief index of affective job satisfaction. Group \& Organization Management, 37(3), 275-307.

Veiga, J. F. (1983). Mobility influences during managerial career stages. Academy of Management Journal, 26, 64 - 85.

Wheeler, K. G., \& Miller, J. G. (1990). The relation to career and family factors to the expressed minimum percentage pay increase required for relocation. Journal of Management, 16, 825 - 834.

Yulianto, V. I. (2011). Is the past in another country? A case study of rural urban affinity on mudiklebaran in middle Java. Journal of Indonesian Social Sciences and Humanities, 4, 49-64. 
Tabel 1 Kondisi Demografi Responden

\begin{tabular}{|c|c|c|c|c|c|}
\hline & Number & (\%) & & Number & $(\%)$ \\
\hline Lokasi & & & Jenis Kelamin & & \\
\hline Jawa-Bali & 67 & 37.9 & Pria & 149 & 84.2 \\
\hline Luar Jawa-Bali & 110 & 62.1 & Wanita & 28 & 15.8 \\
\hline Kantor & & & Masa Kerja di & & \\
\hline Kantor Pusat & 29 & 16.4 & organisasi (tahun) & & \\
\hline Kantor Wilayah & 87 & 49.2 & $<2$ & 5 & 2.8 \\
\hline KPPN A1 & 37 & 20.9 & $2-4$ & 10 & 5.6 \\
\hline KPPN A2 & 24 & 13.6 & $4-6$ & 10 & 5.6 \\
\hline Posisi & & & $6-8$ & 1 & 0.6 \\
\hline Eselon III & 10 & 5.6 & $8-10$ & 19 & 10.7 \\
\hline Eselon IV & 69 & 39 & $10-12$ & 22 & 12.4 \\
\hline Pelaksana & 98 & 55.4 & $12-14$ & 21 & 11.9 \\
\hline Golongan & & & $14-16$ & 15 & 8.5 \\
\hline s.d Golonganll & 21 & 23.2 & $16-18$ & 12 & 6.8 \\
\hline Golongan III & 122 & 68.9 & $18-20$ & 19 & 10.7 \\
\hline Golongan IV & 14 & 7.9 & $>20$ & 43 & 24.3 \\
\hline Usia (tahun) & & & Masa Kerja di instansi & & \\
\hline $21-30$ & 33 & 18.6 & saat ini (tahun) & & \\
\hline $31-40$ & 74 & 41.8 & $<1$ & 44 & 24.9 \\
\hline $41-50$ & 45 & 25.4 & $1-2$ & 78 & 44.1 \\
\hline$>50$ & 25 & 14.1 & $3-4$ & 33 & 18.6 \\
\hline Status Pasangan & & & $4-5$ & 12 & 6.8 \\
\hline Bekerja & 62 & 42.5 & $>5$ & 10 & 5.6 \\
\hline Tidak Bekerja & 66 & 47.4 & Pengalaman Mutasi & & \\
\hline Tidak ada & 18 & 10.2 & Tidak ada / & & \\
\hline Status Pernikahan & & & penempatan awal & 12 & 6.8 \\
\hline Menikah & 159 & 89.85 & 1 kali & 20 & 11.3 \\
\hline Belum Menikah & 18 & 10.2 & 2 kali & 25 & 14.1 \\
\hline Pendidikan & & & 3 kali & 41 & 23.2 \\
\hline SMA/D1 & 15 & 8.5 & 4 kali & 31 & 17.5 \\
\hline D3 & 31 & 17.5 & 5 kali & 8 & 4.5 \\
\hline S1/D4 & 87 & 49.2 & $>5$ kali & 40 & 22.6 \\
\hline S2/Master & 44 & 24.9 & & & \\
\hline
\end{tabular}

Tabel 2 Hasil Uji Cronbach Alpha

\begin{tabular}{lrr}
\hline \multicolumn{1}{c}{ Variabel } & \multicolumn{1}{c}{$\begin{array}{c}\text { Jumlah } \\
\text { Pertanyaan }\end{array}$} & Alpha $(\alpha)$ \\
\hline Kepuasan & 25 & .8807 \\
Relokasi & 25 & .8 \\
$\quad$ Karir & 4 & .8627 \\
$\quad$ Dukungan & 6 & .8044 \\
Organisasi & 5 & .6317 \\
$\quad$ Preferensi Lokasi & 5 & .6036 \\
Dukungan Keluarga & 5 & .7471 \\
$\quad$ Sosialkultural & & \\
\hline
\end{tabular}


Tabel 3 Hasil Uji Korelasi

\begin{tabular}{lrrrrrrr}
\hline \multicolumn{1}{c}{ Variable } & $\begin{array}{c}\text { Mea } \\
\mathrm{n}\end{array}$ & $\begin{array}{l}\text { Std. } \\
\text { Dev }\end{array}$ & \multicolumn{1}{c}{1} & 2 & 3 & 4 & 5 \\
\hline 1. Kepuasan & 3.54 & .47 & 1.000 & & & & \\
2. Karir & 5.52 & 1.05 & .106 & 1.000 & & & \\
3. Dukungan & 4.64 & 1.11 & $.419^{\star \star}$ & $.392^{\star \star}$ & 1.000 & & \\
Organisasi & 4.76 & 1.04 & $.280^{\star \star}$ & .076 & $.271^{\star \star}$ & 1.000 & \\
4. Preferensi Lokasi & 5.71 & .88 & -.034 & .122 & .058 & $.199^{\star \star}$ & 1.000 \\
5. Dukungan keluarga & 5.46 & .98 & $.328^{\star \star}$ & .109 & $.278^{\star \star}$ & $.467^{\star \star}$ & $.165^{*}$ \\
6. Sosialkultural & & & & & & & \\
\hline
\end{tabular}

\section{Tabel 4 Hasil Regresi}

\begin{tabular}{|c|c|c|}
\hline Variables & $\begin{array}{l}\text { Parameter } \\
\text { estimates }\end{array}$ & t-stats \\
\hline Konstanta & $2.488^{\star \star}$ & 3.52 \\
\hline Karir & -.012 & -.33 \\
\hline Dukungan Organisasi & $.129 \star \star$ & 3.18 \\
\hline Preferensi Lokasi & $.067^{*}$ & 1.73 \\
\hline Dukungan keluarga & -.053 & -1.22 \\
\hline Sosialkultural & $.069 *$ & 1.71 \\
\hline Lokasi & $-.217^{\star}$ & -2.12 \\
\hline Unit (regional) & .130 & 0.95 \\
\hline Unit (A1) & .031 & 0.24 \\
\hline Unit (A2) & .235 & 1.46 \\
\hline Posisi (Es IV) & .167 & 1.19 \\
\hline Posisi (Es III) & $.567^{\star}$ & 2.47 \\
\hline Jenis Kelamin & -.091 & -.89 \\
\hline Pendidikan D3 & -.140 & -.77 \\
\hline Pendidikan Sarjana & -.192 & -1.3 \\
\hline Pendidikan Master & -.260 & -1.47 \\
\hline Kelompok Usia-1 & .277 & .56 \\
\hline Kelompok Usia-2 & .240 & .52 \\
\hline Kelompok Usia-3 & .084 & .19 \\
\hline Kelompok Usia-4 & -.067 & -.14 \\
\hline Kelompok Usia-5 & .364 & .58 \\
\hline Status Pernikahan & .067 & .4 \\
\hline Masa kerja-1 & -.148 & .54 \\
\hline Masa kerja-2 & .315 & .79 \\
\hline Masa kerja-3 & .360 & .62 \\
\hline Masa kerja-4 & .070 & .16 \\
\hline Masa kerja-5 & .250 & .54 \\
\hline Masa kerja-6 & .368 & .75 \\
\hline Masa kerja-7 & .430 & .87 \\
\hline Masa kerja-8 & .292 & .58 \\
\hline Masa kerja-9 & .120 & .24 \\
\hline Masa kerja-10 & .501 & .96 \\
\hline Masa kerja unit-1 & .045 & .51 \\
\hline Masa kerja unit-2 & .039 & .35 \\
\hline Masa kerja unit-3 & -.072 & -.42 \\
\hline Masa kerja unit-4 & -.0230 & -.15 \\
\hline 1 kali mutasi & -.140 & -.57 \\
\hline 2 kali mutasi & -.224 & -.82 \\
\hline 3 kali mutasi & -.280 & -1 \\
\hline 4 kali mutasi & -.278 & -.98 \\
\hline 5 kali mutasi & -.148 & -.47 \\
\hline 6 kali mutasi & -.198 & -.66 \\
\hline
\end{tabular}

$\mathrm{R}^{2}=0.453$

Adjusted $\mathrm{R}^{2}=0.252$

$\mathrm{N}=178, \mathrm{~F}=2.45$, Prob. $\mathrm{F}<0.01 ;^{*}<0.05 ;^{* *}<0.001$ 